\title{
¿Más allá del dualismo? \\ Reflexiones sobre la noción de "cuerpo" en el culto a María Lionza (Venezuela) ${ }^{1}$
}

\author{
Beyond Dualism? \\ Reflections on the Notion of "Body" \\ in the Cult of María Lionza (Venezuela)
}

Roger Canals

Universitat de Barcelona

\section{RESUMEN}

¿Cómo se concibe el cuerpo en el culto a María Lionza? ¿Qué papel juega la corporalidad en los rituales de posesión? ¿Qué puntos en común presenta la visión del cuerpo que opera en este culto con la que predomina en la sociedad europea? El argumento principal de este texto es que en el culto coexisten dos visiones sobre el cuerpo: por una lado, una visión propia de lo que podría llamarse "la ontología naturalista" que se hace patente en las entrevistas y que enfatizaría la discontinuidad entre cuerpo y alma, y, por otro lado, una visión de carácter más analogista que se manifiesta básicamente en las acciones que llevan a cabo los creyentes durante los rituales y que pondría de relieve la continuidad entre la parte material y la parte inmaterial del ser humano. Los practicantes del culto se mueven permanentemente - a veces de forma inconsciente, a veces con fines claramente intencionales- entre ambas perspectivas. Desde el punto de vista metodológico, esta ambivalencia sólo puede comprenderse si se comparan los datos etnográficos obtenidos mediante diferentes técnicas de investigación -entrevista, observación participante o uso de las técnicas audiovisuales, entre otras.

Palabras clave: Culto a María Lionza, Rituales de posesión, Persona, Imagen, Venezuela, Discurso.

\section{SUMMARY}

How is the body conceived in the cult of María Lionza? What role does corporality play in possession rituals? What similarities exist between the vision of the body common to this cult and that which predominates in European society? This text argues that two

\footnotetext{
${ }^{1}$ Para Paco, quien tanto me ha ayudado e inspirado en el estudio del culto a María Lionza.
} 
different visions of the body exist in the cult: on the one hand, there is a naturalist vision, clearly revealed in interviews, which emphasizes the discontinuity between body and soul. On the other hand, there is a more analogist vision, manifested in the actions carried out by the believers during the rituals, which highlights the continuity between the material and immaterial aspects of human beings. The followers of this cult constantly oscillate - at times unconsciously and at times with clear intention- between these two perspectives. From a methodological standpoint, this ambivalence can only be understood by comparing ethnographic data obtained through various research techniques, such as interviews, participant observation or the use of audiovisual techniques.

Key words: Cult of María Lionza, Possession Rituals, Person, Image, Venezuela, Discourse.

Hagan pues y observen todo lo que les digan, pero no imiten su conducta, porque dicen y no hacen (Mateo 23,2-3)

Cualquier antropólogo que haya hecho trabajo de campo habrá experimentado en más de una ocasión la distancia existente entre el ámbito del discurso y el ámbito de la acción o, dicho en otras palabras, entre lo que la gente dice y lo que la gente hace. En efecto, una cosa es cómo los individuos definen verbalmente su identidad, sus señas culturales o su forma de vivir en sociedad, y otra, a menudo muy distinta, son los comportamientos e interacciones sociales en que supuestamente estos rasgos definitorios deberían plasmarse y hacerse visibles. Este desajuste entre el registro discursivo y el registro, digamos, de la experiencia, parece plantear un problema de orden metodológico: ¿debemos dar prioridad en estos casos a lo que la gente dice - es decir, a los datos obtenidos mediante la entrevista- o, en cambio, a lo que vemos que la gente hace —es decir, a los datos obtenidos mediante la observación participante? Lo que propongo en este texto es considerar la divergencia entre las informaciones obtenidas mediante la entrevista y las informaciones obtenidas mediante la observación como un hecho significativo antropológicamente que debe ser tomado en cuenta en la reflexión posterior a la recogida de datos. Como mostraré a continuación, es a menudo en la discordancia entre la palabra y la experiencia, entre lo que uno dice y lo que uno hace, donde el antropólogo puede vislumbrar tanto el sentido de la acción como la función social del discurso.

Si he empezado este artículo por una apreciación de carácter metodológico es porque el estudio sobre la noción de "cuerpo" en el culto a María Lionza, que aquí presentaré, parte precisamente del análisis de la distancia entre el ámbito del discurso racional, consciente y intencional de los informantes y el ámbito de las acciones cotidianas y de las interacciones corpora- 
les. La tesis básica del texto podría resumirse así: mientras que el discurso "oficial" de los creyentes en relación a su corporalidad se construye sobre la base de una separación tajante entre el alma y el cuerpo, las prácticas corporales que llevan a cabo durante y fuera de los rituales de posesión, así como algunos comentarios hechos más allá del ámbito de la entrevista formal, revelan la existencia dentro del culto de una concepción mucha más compleja sobre la relación entre el principio inmaterial y el principio material del hombre, en la que estos no aparecen como claramente separados sino como inextricablemente unidos. Examinar cómo coexisten ambas concepciones dentro del culto es el objetivo primordial del presente artículo. En segundo lugar, nos proponemos comparar la noción del "cuerpo" dentro del culto a María Lionza con la que predomina en la sociedad occidental ${ }^{2}$.

Sin embargo, antes de adentrarnos específicamente en dichas cuestiones, es preciso aportar algunas informaciones básicas acerca del culto a María Lionza en Venezuela.

\section{EL CULTO A MARÍA LIONZA HOY}

El culto a María Lionza constituye uno de los ejemplos paradigmáticos de este conjunto de prácticas rituales muy extendidas en el Caribe y América del Sur que se ha venido llamando "cultos afroamericanos" (Mintz y Price 1992) y que incluirían, entre otros, la Umbanda, la Santería cubana, los Misterios Dominicanos o el Palerismo. Los orígenes remotos de este culto deberían encontrarse en el choque que se produjo en América entre indígenas, esclavos africanos y españoles en épocas de la conquista (Barreto 1990, 1995, 1998; Clarac de Briceño 1970, 1983, 1996; Garmendia 1980; Pollack-Eltz 1972, 1994). La colisión de dichas "tradiciones culturales" —que en ningún caso constituían unidades homogéneas - habría propiciado el nacimiento de expresiones religiosas originales, síntesis creativa de las anteriores, que deberían sufrir, ya durante el siglo XX, otras influencias decisivas para su desarrollo, como el espiritismo kardecista, el oscurantismo o una suerte de orientalismo sui generis. Esta biografía hecha de mezclas, fusiones e influencias recíprocas ha provocado que todavía hoy estos cultos, íntimamente emparentados entre sí, reciban la calificación de cultos

\footnotetext{
${ }^{2}$ El término "Sociedad occidental" es claramente ambiguo. Sin embargo, lo utilizo aquí para designar la cosmovisión propia de la cultura euro-norteamericana, entendiendo que esta cosmovisión no se encuentra geográficamente delimitada sino que ha alcanzado una dimensión global.
} 
"Sincréticos" - a pesar de las reiteradas críticas que se han venido elaborando contra este concepto (ver, por ejemplo, Amselle 1999). De hecho, es cierto que si algún aspecto sorprende de dichas prácticas rituales - y especialmente del culto a María Lionza - es su naturaleza dinámica y aglutinante, su capacidad para incorporar nuevos elementos simbólicos y materiales tejiendo así lazos con otras religiones y sistemas de creencias (Fernández y Barreto 2001-2002).

El culto a María Lionza se practica esencialmente en las grandes ciudades venezolanas y en la región de Yaracuy, en el centro oeste del país, donde se halla la Montaña de Sorte, centro de peregrinaje de los creyentes. Éstos proceden de diferentes capas sociales de la población venezolana, si bien la mayoría son de extracción popular. Además, cabe decir que el culto integra creyentes que se definen como "blancos", "negros" o "mestizos". Los creyentes son muy conscientes de la pluralidad étnica que caracteriza el culto y sienten especial orgullo por ello. Es precisamente éste uno de los argumentos que presentan para defender el carácter abierto y integrador de esta "religión", que se situaría más allá de las divisiones sociales y raciales del país: María Lionza sería así la diosa de todos los venezolanos y venezolanas sin excepción alguna. A pesar de ser reconocido como un culto autóctono y típicamente venezolano - lo que hace que esté empapado de un fuerte nacionalismo-, su práctica se ha extendido durante los últimos decenios hacia países cercanos como Colombia, Brasil o Puerto Rico, así como a Estados Unidos y Europa, especialmente en España. Tres son los factores principales que explicarían este nomadismo: en primer lugar, los procesos migratorios, en segundo lugar, el impacto de una industria del esoterismo que ha alcanzado ya un alcance mundial y, finalmente, la presencia masiva del culto en Internet, ya sea en blogs o páginas Web, ya sea en las redes sociales como Facebook (Canals 2011b).

La figura principal del culto es María Lionza, una diosa poliédrica, descrita y representada según las versiones como una mujer blanca, india, mestiza o negra, a veces bondadosa, a veces maléfica, a veces con inexplícito carácter sexual, a veces como una diosa maternal desprovista de sensualidad alguna (Manara 1995; Jiménez Sierra 1971; Salazar 1998; Canals 2010a). María Lionza es acompañada por un sinfín de otros espíritus - también llamados dioses o hermanos - agrupados en diferentes cortes o grupos jerarquizados según una lógica piramidal formando conjuntamente un gran panteón. Encontramos así la Corte Vikinga, la Corte Chamarrera o la Corte Militar, entra muchas otras. Entre todos los dioses, espíritus o hermanos que constituyen el panteón, son especialmente relevantes el Indio Guacaipuro y el Negro Felipe, máximos representantes de la corte india y de la corte africana respectivamente. Junto a María Lionza, éstos dioses constituyen un 
conjunto celestial llamado Las Tres Potencias, también conocido como La Trinidad Venezolana, suerte de expresión simbólica del carácter mestizo de la nación. María Lionza es una figura altamente popular en Venezuela, que encontramos incluso más allá del ámbito del culto, ya sea en el mundo del arte, en la publicidad, en el espacio público o incluso en la esfera política, donde son recurrentes las referencias a una diosa elevada a la categoría de icono nacional como lo fuera el mismo Simón Bolívar.

El culto a María Lionza reúne rituales de curación, adivinación, iniciación y purificación, en los cuales son frecuentes los episodios de trance. La posesión en el culto es más o menos violenta según el caso: puede ir desde trances muy tranquilas donde la alteración corporal es mínima, hasta posesiones violentas, que pueden desembocar en episodios de automutilación (ver Ferrándiz 1992, 1995, 1996, 1999, 2002, 2004). Es importante resaltar que muchos son los creyentes que se definen como adeptos al culto, sin por ello participar activamente en ceremonias grupales con episodios de trance. Encontramos, en efecto, una forma íntima de adorar a la diosa que tiene lugar esencialmente en los altares domésticos. La cultura material —imágenes religiosas, ofrendas, velones, piezas de ropa- juega un papel importantísimo en el culto. El ejemplo más claro de ello es sin duda alguna los magníficos altares delante de los cuales se desarrollan los rituales. Finalmente, señalamos la fuerte significación que tienen en el culto aquellos fenómenos relacionados con el acto de ver, ya sean sueños, visiones, apariciones o creencias vinculadas con la mirada, como el muy conocido "mal de ojo", íntimamente emparentado con el sentimiento negativo de la envidia (Canals 2011a). De hecho, y como lo veremos a continuación, existe en el culto una estrecha relación entre los cuerpos, los objetos y los sueños que atañe también la cuestión que aquí nos ocupa, a saber: el vínculo entre identidad y cuerpo, el lazo que une el principio inmaterial y el principio material de la persona.

\section{EL DISCURSO DE LA DISCONTINUIDAD}

En su libro Par-delà nature et culture (2005), Philippe Descola define el naturalismo como una "ontología moderna" basada en "una continuidad de la fisicalidad de la entidades del mundo y una discontinuidad de sus interioridades ${ }^{3}$ (2005: 242). Esta ontología, cuyos orígenes deberían encontrarse en el dualismo cristiano y la filosofía post-renacentista, estaría en la

\footnotetext{
3 Todas las traducciones son mías.
} 
base de la noción occidental de ser humano como un ente constituido por dos principios ontológicamente distintos e irreductibles entre sí: el alma (interioridad) y el cuerpo (fisicalidad) ${ }^{4}$. Desde esta óptica, el cuerpo se define como una entidad material, orgánica, natural: es aquél principio que uniría al ser humano con el conjunto de los seres vivos e inanimados. El alma, en cambio, es un principio inmaterial e inmortal, huella de dios en el hombre, origen de todos aquellos atributos que darían al ser humano su especificidad y su superioridad: el lenguaje, la capacidad reflexiva, la sensibilidad, la conciencia moral, en definitiva, la cultura. Este dualismo naturalista, basado en la oposición Naturaleza-Cultura, sería todavía hegemónico en el mundo, digamos, occidental, a pesar de la pérdida de peso de la religión como discurso público. Y es que aunque la ciencia, que es quien detenta hoy en día la hegemonía de los discursos "fuertes" (Latour 1992), se defina como irrenunciablemente materialista, entendemos que todo lo que tiene que ver con "los principios del alma" - a saber, la identidad, la personalidad o la cultura- pertenece a un dominio cualitativamente diferente al del cuerpo y, en cierta forma, singulariza al ser humano respecto a los otros seres vivos.

Descola opone a esta ontología naturalista tres ontologías más: el totemismo, el animismo y el analogismo. Es precisamente en ésta última donde el antropólogo francés sitúa los cultos afroamericanos (2005: 296). El analogismo, que en Europa antecedería históricamente al naturalismo y que encontraría su último representante teórico en la figura de Michel de Montaigne (1533-1592), se caracterizaría por ser una ontología que "fracciona el conjunto de los seres en una multiplicidad de esencias, de formas y de sustancias separadas por mínimas diferencias" (Descola 2005: 280). De esta forma, si el naturalismo simplifica la taxonomía de los seres existentes repartiéndolos en dos grupos netamente diferenciados — los que tienen "cultura" y los que carecen de ella-, el analogismo establece entre ambos colectivos un complejo sistema de continuidades que ponen en entredicho la división Naturaleza-Cultura o Naturaleza-Sociedad, y cuyo ejemplo más conocido sean probablemente las célebres "cadenas del Ser" del medievo europeo. En lo que a la constitución del ser humano se refiere, las diferen-

\footnotetext{
${ }^{4}$ Descola afirma que la distinción entre fisicalidad e interioridad que él establece no debe interpretarse como una universalización de la separación alma/cuerpo propia de occidente, bien al contrario: la distinción entre cuerpo y alma de la tradición occidental debe concebirse como una ejemplificación concreta de una distinción entre material e inmaterial, presente en todo universo cultural. Habría pues un dualismo universal presente en todas las ontologías. La tesis de un "dualismo natural" es defendida por Astuti (2001) desde una perspectiva cognitivista.
} 
cias entre ambas ontologías serían también notables: mientras que el dualismo naturalista establecería una separación radical entre el alma y el cuerpo, el analogismo pensaría el lazo entre el principio material y el principio inmaterial del ser humano en términos, ya no de ruptura, sino de progresión. Alma y cuerpo — es decir, Cultura y Naturaleza- no se concebirían pues como dos sustancias o esferas excluyentes e irreductibles entre sí, sino como los dos extremos de una larga sucesión de propiedades o de seres que irían desde lo puramente material hasta lo puramente espiritual. Según Descola, los cultos afroamericanos se estructurarían sobre la base de una ontología analogista, lo que explicaría la importancia que en ellos juega el sacrificio (Descola 2005: 317), la posesión (Ibid.: 296) y todos los elementos intermediarios entre un mundo y otro, como por ejemplo los santos e imágenes religiosas (Ibid:: 378).

El esquema clasificatorio de Descola, basado en cuatro ontologías que determinarían tantos "esquemas de la experiencia", puede ser utilizado como punto de partida para analizar la noción de cuerpo que opera dentro del culto a María Lionza y compararla ulteriormente con la que impera en el contexto occidental. La cuestión que se nos plantea es entonces la siguiente: ¿responde la práctica del culto —y más concretamente la concepción del cuerpo que se da en ella- a una lógica analogista (como sostendría Descola) o más bien a una lógica de tipo naturalista?

La respuesta no resulta para nada simple, sobre todo si uno atiende no únicamente a lo que los creyentes dicen acerca de su concepción de "persona" en el contexto de la entrevista, sino también a lo que los creyentes hacen en el marco del ritual e incluso fuera de él. Es también importante tomar en cuenta el contenido de algunos de los comentarios "espontáneos" que uno puede captar durante conversaciones y charlas cotidianas fuera del contexto de la entrevista formal. Por ejemplo, cuando en el marco de una entrevista se pregunta a los creyentes de forma explícita acerca de la lógica y el funcionamiento de los rituales de posesión, éstos acostumbran a expresarse en términos inequívocamente naturalistas (lo que, en principio, parece contradecir la tesis de Descola). En efecto, los creyentes explican la posesión como un proceso de substitución de la persona que se organizaría a partir de los dos principios constituyentes del ser humano: por un lado, el cuerpo (principio material) y, por otro lado, el alma (principio inmaterial). La posesión consistiría pues en una substitución de almas dentro de un mismo cuerpo: el médium o materia expulsaría su alma y dentro de "su" cuerpo vacío incorporaría el alma de un dios o un muerto hasta que éste se fuera dejando el cuerpo de nuevo vacío para que recuperara "su" alma original. En este discurso, el cuerpo se define como un simple envoltorio del alma, como un ente desacralizado y neutro, como un mero caparazón 
que hospeda el principio inmortal e inmaterial del ser humano, única fuente de cultura e identidad personal. El cuerpo es así desvalorizado como un ente orgánico, perecedero, impersonal: “Un cuerpo sólo es un cuerpo. Tengo este cuerpo como podría tener cualquier otro. Lo que importa, lo que me hace ser quien soy, es el alma", decía una practicante del culto de Caracas. La falta de conexión entre el alma y el cuerpo explicaría, según los creyentes, que en el culto cualquier médium pueda recibir en su cuerpo todo tipo de espíritu, indiferentemente de su género o pertenencia étnica o social. Es frecuente en el culto, en efecto, que médiums hombres reciban espíritus femeninos o que, por ejemplo, materias de piel blanca sean poseídas por espíritus "africanos", "indios" o "mestizos", o viceversa.

Una experiencia de trabajo de campo pone en evidencia esta lógica de la discontinuidad entre el alma y el cuerpo que caracteriza el discurso de tipo naturalista. Me encontraba yo en la ciudad Maracaibo haciendo trabajo de campo con un grupo de creyentes, con quienes vivía desde hacía ya unas semanas. Ellos estaban acostumbrados a que yo les filmase dentro y fuera del ámbito religioso. Sin embargo, nunca habían visto el contenido de mis cintas. Un día decidí reparar esta situación y organicé una proyección de las ceremonias rituales que había registrado. Con este evento buscaba, en primer lugar, crear una suerte de feed-back, es decir, reforzar el lazo que me unía con los creyentes mostrándoles parte de mi trabajo. Pero más allá de este fin relacional, esta proyección tenía una finalidad performativa: provocar que los creyentes explicaran con precisión y en referencia a imágenes de sí mismos las alteraciones que su cuerpo y su persona experimentaban durante los episodios de trance. Uno de los comentarios más significativos fue el que hizo John, un hombre habitualmente tranquilo y sereno que recibía durante los trances un gran número de bermanos en su cuerpo. Uno de los espíritus que le bajaba más frecuentemente era el de Changó, un dios proveniente de la Santería Cubana hoy en día extremadamente popular en el culto. Al recibir Changó, la gestualidad y lenguaje corporal de John se veían completamente alterados: "su" rostro se transfiguraba a causa de las muecas, su cuerpo se contorsionaba con movimientos violentos y "su" voz, habitualmente cálida y pausada, adquiría un tono grave y algo siniestro, apenas comprensible. John estuvo mirando una filmación que yo había hecho de un ritual donde "le bajaba" el espíritu de Changó. Miró la cinta con atención pero de forma distendida, inclusive con alguna sonrisa de vez en cuando. John vio un primer plano de su rostro bajo la posesión de Changó y entonces dejó ir un comentario significativo: "vaya con la cara de Changó cuando está bajando!». Este comentario me desconcertó, pues yo esperaba que frente a la imagen de su rostro durante la posesión del dios africano, John dijera algo así como: "mira qué cara pon- 
go yo cuando estoy poseído por Changó!». En efecto, desde mi óptica, parecía evidente que, aunque el alma de John ya no estuviera, el cuerpo que acogía a Changó continuaba siendo "el suyo". Sin embargo, el comentario de John es coherente con la lógica de la discontinuidad entre alma y cuerpo en la que conscientemente él quería situarse. Como hemos dicho, el dualismo naturalista - y, más concretamente, la versión que de él hizo parte de la tradición cristiana- establece que el alma es el dominio de la identidad personal mientras que el cuerpo, en cambio, sólo constituye un soporte cuyo fin es hospedar el principio inmaterial y vital del ser humano. Desde esta perspectiva, resulta lógico que, si el espíritu de John ya no se encontraba en su cuerpo, no hubiera ningún elemento en éste último que permitiera conectarlo con la identidad de su "antiguo inquilino". Todo lo que en este cuerpo sucediera durante el ritual debería pues ser atribuido a aquél que momentáneamente lo habitaba, es decir, a Changó.

Según los adeptos, es a causa de esta total substitución espiritual por lo que los médiums no se acuerdan de nada después de la posesión, y por lo que ningún acto realizado por el dios durante la posesión les puede ser atribuido. De hecho, es habitual que una vez terminado el ritual de posesión, los médiums pregunten a la audiencia acerca de lo que ocurrió. Su amnesia se convierte en la prueba pública de la veracidad de la posesión. Además, el hecho de pedir a los asistentes el relato del ritual provoca que éstos se reúnan de nuevo, concluyendo conjuntamente la experiencia ritual, explicitando y fijando las lecciones aprendidas y reforzando a través de la palabra el sentimiento de grupo. Es este hecho un ejemplo claro de que lo que sucede después del ritual — como lo que tiene lugar justo antesforma parte del ritual $y$ debe ser estudiando como parte integrante del mismo.

\section{LA CONTINUIDAD EN ACCIÓN}

El discurso intencional y consciente de los creyentes que podemos obtener mediante la entrevista tiende pues a reforzar la concepción dual de la persona, escindida entre cuerpo y alma. Algo muy distinto ocurre cuando lo que tomamos en cuenta son, por un lado, las acciones de los creyentes, y, por otro lado, los comentarios que éstos hacen, ya no en el contexto de la entrevista, sino en el seno de conversaciones o situaciones cotidianas. Se trataría en este caso de una palabra no incitada directamente por el antropólogo ni dirigida especialmente a él, sino de un discurso que se inscribe dentro de la dinámica de la acción sin pretender explicarla de forma supuestamente objetiva. Al tomar en cuenta estas variables nos percatamos que dentro del 
culto opera, en la práctica, una concepción más bien gradual — o, si se prefiere, analogista - entre el principio material e inmaterial del hombre, que tiende a divinizar el cuerpo y a materializar el alma.

Dos reflexiones relativas a la posesión servirán para ilustrar esta tesis. Si bien es cierto que dentro de la lógica del culto cualquier médium o «materia” puede ser poseído por cualquier espíritu, también es cierto que los creyentes confiesan que hay cuerpos más aptos que otros a recibir según qué dioses. Así, muchas practicantes del culto dejan entender que para recibir los espíritus indios es necesario estar "en buena forma" — pues se trata de espíritus muy "fuertes" — mientras que, por ejemplo, es improbable que una persona poco cultivada y con poca capacidad reflexiva y oratoria incorpore el espíritu de un hombre sabio e ilustrado como lo fuera el profesor Lino Valles. Debe haber pues una cierta afinidad - $\mathrm{O}$, si se prefiere, una continuidad - entre el cuerpo receptor y las características corporales atribuidas al espíritu que en él momentáneamente se incorpora, así como entre la personalidad del médium y la personalidad del dios que lo posee. Si esta continuidad resulta necesaria, es, en primer lugar, porque cada espíritu se define por una gramática corporal concreta. En efecto, los dioses quizás no estén dotados de un cuerpo en el sentido físico término, pero al menos sí poseen una cierta corporeidad, es decir, un conjunto de patrones sociales que regulan la acción del cuerpo. Los espíritus africanos, por ejemplo, se mueven y hablan de una determinada manera, muy distinta a la que manifiestan los espíritus médicos. Sólo viendo los movimientos de los médiums poseídos, un antropólogo mínimamente familiarizado con el culto puede adivinar qué espíritu se alberga en su cuerpo. Si el médium hace movimientos femeninos sensuales, es probable que el espíritu se trate de una joven india; si el cuerpo hace gestos violentos que llegan hasta las automutilaciones, uno puede deducir que se asiste a la posesión de un espíritu africano o vikingo; y por ende, si el médium "decide" sentarse, coger un bastón y hablar pausadamente, existen fuertes probabilidades de que el espíritu que haya bajado sea el de un viejo chamarrero.

De hecho, ocurre también que muchos médiums van pareciéndose a los espíritus que incorporan a medida que pasa el tiempo. Así, algunos hombres temen feminizarse por el hecho de acoger contra su voluntad un gran número de espíritus femeninos. Otros afirman sentirse más felices por el hecho de haber incorporado en los últimos meses un gran número de espíritus chamarreros, muy dados a la broma y a la risa. De hecho, frecuentemente los creyentes comentan que, a fuerza de incorporar repetidamente un espíritu, a veces el cuerpo pasa a apropiarse de ciertos rasgos definitorios de la corporalidad de éste, que pueden hacerse visibles incluso fuera del ámbito de la posesión. Los espíritus, como decía una creyente, acaban siendo "parte de 
tì: la noción de persona se ve así amplificada, multiplicada, pasando de la visión unívoca del "yo" cartesiano propio del sistema naturalista hacia una personalidad múltiple y cambiante, hecha a base del conglomerado de diferentes principios vitales.

Los espíritus llevan pues consigo la memoria del cuerpo en que vivieron o, mejor dicho, la huella del habitus corporal (Bourdieu 1994) que los caracterizó antes de la muerte. Esto es algo consubstancial al alma, es decir, a la persona del muerto o del espíritu. La memoria corporal del espíritu puede incluir todo un conjunto de prácticas que se hacen ya no con el cuerpo, sino en el cuerpo o incluso sobre él. Resulta en este sentido destacable que la mayoría de espíritus pidan ser "disfrazados" durante el trance. A los médiums poseídos por espíritus indios se les pone una cinta en la frente, mientras que los que son poseídos por un espíritu vikingo precisarán de una capa. El alma que "desciende" mantiene igualmente durante la posesión un conjunto de facultades sensitivas o secundarias que, desde una perspectiva naturalista, fácilmente relacionaríamos con el cuerpo, más no con el alma. Muchos espíritus, por ejemplo, piden beber, fumar o ser bañados con colonia. Algunos gustan de la buena comida y ordenan manjares para satisfacer su hambre.

La cuestión de la experiencia corporal y el conocimiento sensitivo juega un papel decisivo en el culto. En contra de los que suelen decir muchos creyentes, que pretenden dar prestigio al culto definiéndolo en términos muy intelectualistas, el proceso de iniciación al culto —esto es, la capacidad de expulsar su espíritu para acoger uno foráneo- conlleva, sobre todo un aprendizaje corporal, es decir, un trabajo sobre el cuerpo, mas no sobre el alma (ver Ferrándiz 1999, 2002, 2004). Así, el culto a María Lionza ha desarrollado toda una compleja significación sobre los sentidos y las experiencias corporales en tanto que estrategias perceptivas y cognitivas que requieren ser abordadas desde la perspectiva de una antropología de los sentidos (ver Ingold 2002 o Pink 2009).

En este sentido, quisiera evocar una experiencia de mi propio trabajo de campo que me parece especialmente aclaratoria. Me encontraba yo con un grupo de culto ubicado en Baruta, uno de los núcleos del extrarradio de Caracas, a finales del 2006. Nos conocíamos bien, y yo había filmado varios de los rituales de posesión que regularmente realizaban, entre ellos dos en los que bajó la misma Reina María Lionza, algo poco frecuente en el culto5 . Pero ese día, la materia principal del grupo me dijo, delante de todo el mundo, algo que me dejó desconcertado: "Roger, tú no puedes

\footnotetext{
${ }^{5}$ Este ritual constituye una de las escenas de mi película Rostros de una divinidad venezolana (CNRS-Images, 2008).
} 
continuar estudiando los rituales de posesión sin haber estado nunca poseído; sería como pretender escribir un manual de natación sin haber puesto nunca los pies en el agua". Intenté educadamente rechazar la propuesta, argumentando que yo era antropólogo, mas no creyente, y que mi rol debía limitarse a una observación relativamente distanciada, cuya finalidad no era la conversión personal, sino el estudio "objetivo" del culto. Pero de poco sirvieron mis palabras: se fue creando una suerte de entusiasmo popular por verme poseído e incluso un chico joven propuso filmarme en trance. Jugando mi última carta, expuse que desconocía la técnica necesaria para adentrarme en estos estados extáticos. Pero la médium principal restó importancia a este hecho, y dijo que si yo me concentraba ella sería capaz de "pasarme" los espíritus sin que yo tuviera que hacer prácticamente ningún esfuerzo. Resignado, acepté el reto. Primero, me purificaron con un baño, mezcla de agua, ron, perfumes y miel. Luego me sentaron frente a un majestuoso altar lleno de estatuas, velones y ofrendas, presidido por las tres divinidades principales del culto: María Lionza, el Negro Felipe y el Indio Guacaipuro. Tres miembros del grupo estaban fumando tabaco a mi alrededor, expulsando el humo sobre mi cuerpo. A mis espaldas, la médium recitaba una oración en la que pedía a los espíritus que poseyeran mi cuerpo. ¿Qué se suponía que yo debía hacer en aquél momento? Yo sabía que no iba a ser poseído: ni era creyente del culto ni pertenecía a una cultura donde los rituales de posesión tuvieran sentido alguno. Reflexionando, me di cuenta de que tenía dos opciones de actuación: una posibilidad era fingir una posesión, es decir, hacer ver que yo expulsaba mi alma y que luego me entraba un espíritu en mi cuerpo. Debería en este caso tambalearme y ponerme a gesticular como tantas veces había visto hacer a los médiums marialionceros. Pero esta posibilidad era deshonesta y, sobre todo, absolutamente disparatada: en primer lugar, porque mi supuesta posesión no hubiera resultado para nada creíble — no era ni soy capaz de moverme como lo hacen los médiums en trance- y, en segundo lugar, porque dicha estrategia suponía engañar a unos creyentes que se habían convertido ya en mis amigos, y además hacerlo de la forma más baja y condenable posible dentro de la lógica del culto, a saber: fingiendo una posesión. Habitualmente, los médiums acusados de simular trances — que reciben el nombre de plataneros - son menospreciados por el resto de creyentes y expulsados definitivamente del culto. Fingir la posesión es considerado como una ofensa grave a los hombres y a los dioses. Éste era un riesgo que yo ni quería ni podía asumir. La otra opción, quizás la más sincera, era permanecer allí sin hacer nada, inmóvil frente al altar, evidenciando con toda honestidad que si yo no estaba poseído era sencillamente porque no podía estarlo. Esta opción presentaba sin embargo otro problema: suponía 
desmentir públicamente la palabra de la médium principal del grupo, quien había afirmado que era capaz de hacerme caer en trance con el simple uso de sus habilidades espirituales y de sus oraciones. Era muy probable que, para no ver mermada su autoridad delante de los otros, la médium me acusara de no haber puesto de mi parte, de haberme negado voluntariamente a caer en trance para desmentirla públicamente. Reflexionando sobre estas cuestiones empecé a temblar de frío. Tenía todavía el cuerpo mojado por la purificación previa al inicio del ritual y el viento del atardecer empezaba a soplar. Yo no di ninguna importancia a éstos escalofríos ni a la baja temperatura que estaba alcanzando mi cuerpo. Sin embargo, dichos síntomas corporales fueron rápidamente interpretados por la médium como una señal inequívoca de la presencia de espíritus en mi cuerpo, es decir, como la prueba del inicio de un proceso de posesión. Yo me quedé unos segundos temblando hasta que la médium decidió finalizar la experiencia: desde su perspectiva, yo había experimentado una posesión - ciertamente incompleta- durante la cual un espíritu (probablemente un vikingo, dijo ella) había parcialmente penetrado mi cuerpo.

La explicación de la médium era plenamente coherente con la lógica del culto: los practicantes describen el momento de entrada de los espíritus, cuando el alma del médium se está yendo, pero el espíritu que se aproxima todavía no está allí, como un escalofrío que provoca una repentina bajada de la temperatura corporal. Esta sensación sería ocasionada por el hecho de que los espíritus, como los muertos, carecen del calor vital. Existe en el culto toda una "gramática de los sentidos" y las experiencias corporales que se producen con alto valor simbólico: el calor, el olor o el sudor son signos externos de las alteraciones que sobrevienen a la persona en el trance. En el fondo, lo que se evidencia aquí es que el cuerpo hace las veces de ámbito de la verificación de los procesos espirituales. Un ejemplo inequívoco de esto es que uno de los criterios que se toma en consideración para comprobar si un médium está verdaderamente poseído o está sencillamente plataneando es la alteración que experimentan sus ojos. Si los ojos del médium están girados hacia dentro — como mirando hacia el interior del cuerpo- significa que la posesión es real. Es este un elemento que viene a confirmar lo que avanzábamos anteriormente, a saber, que los espíritus llevan consigo una corporeidad asociada que pone de nuevo en cuestión la neta separación entre cuerpo y alma que aparece conceptualizada en los discursos de los creyentes.

Esta experiencia de trabajo de campo resulta además interesante porque en ella el antropólogo toma su propio cuerpo como objeto de investigación. No es exagerado decir que, en el contexto del ritual, el investigador es desposeído de su propio cuerpo, pues las reacciones que éste último 
experimenta son interpretadas a partir de un marco simbólico que no es el suyo y cuyas reglas desconoce parcialmente. El cuerpo del antropólogo se convierte en terreno de interpretación, en una suerte de "texto abierto" del cual cada uno se apropia en función de sus paradigmas culturales. Por ende, se trata de un ejemplo que muestra bien lo que es, en gran parte, la antropología: el estudio de la pluralidad de interpretaciones que pueden darse sobre un mismo evento —en este caso mi frío y mis temblores- en función de referencias culturales heterogéneas.

Lo que estas dos experiencias de trabajo de campo ponen de manifiesto es que existe en el culto a María Lionza una relación de continuidad entre la parte material e inmaterial del hombre, entre los procesos corporales y los procesos espirituales. Esta lógica de la continuidad tiene igualmente equivalente en el vínculo que los creyentes establecen entre el mundo espiritual y el mundo "natural". En efecto, en las entrevistas formales, los marialionceros describen el ámbito de la Naturaleza en los términos explícitamente cientificistas o mecanicistas propios del dualismo naturalista: el mundo exterior se regiría así por un conjunto de leyes ciegas que nada tendrían que ver con el ámbito de lo espiritual, lo cultural o lo moral. Sin embargo, las observaciones de trabajo de campo vienen a mostrar que la Naturaleza puede también estar dotada de una cierta alma o subjetividad. Esto se hace particularmente evidente en la Montaña de Sorte, centro de peregrinaje de los creyentes. Para adentrarse en ella, hay que pedir permiso a los Don Juanes, suerte de dueños de los elementos naturales -ríos, árboles, rocas, animales, caminos... Quien omita esta regla, puede padecer la venganza de María Lionza, quien es a menudo identificada con la montaña misma (se dice, por ejemplo, que cortar un árbol es hacer daño a $L a$ Reina). Las plantas, los animales y el mundo natural en general, son dotados, en determinados contextos, de un principio de interioridad que en mucho se parece a lo que Descola llama "animismo". Esta suerte de panteísmo se mezcla hoy en día, sobre todo entre los creyentes de clases altas, con una especie de ecologismo místico y algo apocalíptico, ligado al discurso sobre el cambio climático y el daño que la civilización industrializada estaría infligiendo a los recursos naturales. María Lionza, diosa de las montañas y de los ríos, sería también víctima de la destrucción global del planeta.

Es revelador así mismo el doble discurso que tienen los creyentes sobre la ubicación de los espíritus. En efecto, siguiendo una lógica de la discontinuidad, los creyentes defienden que los dioses, cuando no están en los cuerpos de los médiums, se encuentran "allá arriba", es decir, en "el cielo", un ámbito transcendente e inalcanzable, esfera de pura exterioridad. Sólo las almas de los muertos que no han encontrado el reposo definitivo merodean entre los vivos "aquí abajo". De ahí que se utilice el verbo "bajar" 
para describir la llegada de los espíritus en el cuerpo del médium. Pero, de nuevo, esta versión no casa con lo que uno ve durante el trabajo de campo: cuando un médium empieza a ser poseído, el espíritu que "entra" lo hace siempre por los pies. Es, en efecto, por el movimiento acelerado de las piernas como el observador puede deducir que un médium empieza a entrar en trance. De hecho, existe dentro del culto lo que se llama una "posesión de cintura", y que equivale a una posesión incompleta que sólo va de los pies hasta la cadera, que es precisamente la que me habría ocurrido a mí en la experiencia etnográfica relatada anteriormente. Es porque los espíritus vienen del suelo por lo que los médiums no pueden utilizar zapatos durante los rituales. Se pone en evidencia pues que, junto a una noción cristiana de cielo — que subrayaría la discontinuidad entre el ámbito de los vivos y el ámbito de los muertos- habría dentro del culto una concepción mucho más inmanente y próxima de lo sobrenatural, según la cual las almas estarían inextricablemente ligadas a la tierra, una visión que tendería a enfatizar la continuidad entre vivos y muertos, entre transcendencia e inmanencia.

Queda claro cómo, a pesar del discurso de los creyentes, existe en el culto una imposibilidad de pensar el cuerpo sin un alma y el alma sin un cuerpo. Ambos están consubstancialmente ligados, como lo están también vivos y muertos, médiums y dioses, dioses y espacios naturales. Esta ambivalencia entre un discurso naturalista y otro más analogista no concierne únicamente la concepción de cuerpo, sino que impregna todo el culto a María Lionza. Dedico el siguiente apartado a analizar el carácter que toma dicha dicotomía en las imágenes materiales y las imágenes mentales de la diosa.

\section{OBJETOS, CUERPOS Y SUEÑOS}

La palabra "imagen" puede ser entendida de formas muy distintas, a veces aparentemente contradictorias. Como dice Aumont (1990: 3), una primera distinción que cabe hacer es entre las imágenes visuales y las imágenes no visuales, fruto de un uso metafórico del término, como cuando se dice de un poema que crea una "imagen bella" de una persona o de un lugar mediante el juego de las palabras. Me referiré aquí a las imágenes visuales y, más concretamente, a lo que se ha denominado la "imagen representacional". Según Schaeffer, "la definición corriente de representación (o signo) comporta la idea de que ésta figura una cosa que ella no es" (2005: 175), ya sea esta "cosa" representada algo real o imaginario. Por ejemplo, una imagen de Poseidón es una imagen representativa, aunque nosotros no otor- 
guemos existencia fáctica a dicho dios. En cambio, una pintura abstracta no sería una imagen representativa, aunque el título de la misma fuera "Las Ramblas de Barcelona".

Existen evidentemente muchas imágenes de María Lionza, y de ellas se pueden hacer innumerables clasificaciones. En una obra precedente (Canals 2010a), opté por hacer una clasificación a partir de la noción de "Soporte" o medio de transmisión, introducida por Belting (1994, 2004). El autor alemán sostiene que "toda imagen se encuentra necesariamente inscrita en un medio o soporte que hace precisamente posible su visibilidad" (Belting 2004: 8), “incluso nuestras imágenes mentales o interiores" (ibid.). Desde el punto de vista de la experiencia del espectador, la imagen resulta inseparable de su soporte. Ahora bien, desde el punto de vista del análisis, imagen y soporte son claramente separables. En efecto, la imagen no se reduce a su médium, más bien se hace visible "a través de él" y es éste último el que precisamente le sirve como base para su presentación. La imagen, en consecuencia, siempre aparece a través de un soporte, pero no es reducible a él, lo sobrepasa. Este momento de "sobrepasamiento" (dépassement, en francés) de la imagen en relación a su soporte tiene lugar en el momento de la percepción de la imagen, es decir, cuando la imagen se convierte en imagen para un sujeto. Este momento de percepción se revela, según Belting, como la condición indispensable para la existencia de la imagen misma. En efecto, "para que una imagen se realice en tanto que imagen, hace falta un acto de animación que la transporte a nuestra imaginación separándola de su médium-soporte" (Belting 2004: 43). Toda imagen se encuentra pues "en estrecha relación entre un cuerpo que observa y un médium que es observado", entre un soporte que hace la imagen visible y un sujeto que la mira $y$, por así decirlo, la capta "a través" del médium.

Desde la perspectiva de los soportes existirían tres tipos de imágenes de María Lionza: las imágenes materiales, las imágenes corporales y las imágenes mentales (Canals 2010b). Las imágenes materiales son aquellas realizadas por la mano humana con materiales sólidos, tales como pinturas, esculturas, grabados o carteles. Estas imágenes se encuentran en distintos ámbitos de la sociedad venezolana: la esfera religiosa, la artesanía, el "mundo del arte" o la publicidad, para nombrar unos pocos. En la «imagen corporal", en cambio, María Lionza es "encarnada" o "representada" físicamente, ya sea por médiums durante los rituales de posesión, ya sea por bailarinas o actrices de teatro, cine o telenovelas. Por supuesto, no podemos considerar de la misma manera la imagen corporal en el contexto del ritual de posesión y la imagen corporal que nos brinda una actriz durante una representación teatral (aunque la frontera entre ambas imágenes corporales es, en el contexto que aquí nos ocupa, a menudo más tenue de lo que se 
podría imaginar). En el caso de la posesión, se supone que el espíritu de María Lionza reemplaza temporalmente el del médium, mientras que en el escenario, la actriz interpretaría consciente y voluntariamente un papel que ha aprendido previamente. El sentido que se atribuye a estas imágenes corporales es distinto, tanto por la persona cuyo cuerpo sirve de soporte para la presentación de María Lionza, como por el público que asiste a la "representación": en un caso habría substitución espiritual y en el otro no. Pese a las diferencias, el principio que articula ambas imágenes corporales es el mismo: durante la posesión o la representación teatral, el cuerpo de la persona - materia o actriz - actúa como la "base" o el "soporte" a partir del cual se hace visible el espíritu o el papel de María Lionza. Así pues, desde el punto de vista del observador externo, lo que se ve durante un ritual de posesión o una pieza de teatro es sencillamente un cuerpo que no se refiere ya a su identidad ordinaria, sino que sirve como dispositivo de presentación para otro ser, ya sea éste un personaje de ficción, como es el caso del teatro, ya sea éste un espíritu considerado "real", como es el caso de la posesión. Se trata, en definitiva, de un cuerpo convertido en imagen. Finalmente, muchos creyentes consideran que María Lionza puede ser vista directamente durante sueños, visiones o apariciones. Es lo que denominaré aquí la "imagen mental" de la divinidad.

Se podrían incluir otras variables en este estudio sobre las imágenes de María Lionza, concretamente en función del contexto donde se encuentran (por ejemplo, si se trata de imágenes artísticas, religiosas o comerciales) o de la forma cómo representan la figura de la diosa (si aparece como una india, como una mujer blanca o como una mujer mestiza o negra). Me limitaré sin embargo al ámbito de las imágenes religiosas, entendiendo por “imágenes religiosas" las representaciones de la diosa utilizadas en el contexto ritual. Las imágenes materiales más empleadas en el contexto del culto son las estatuillas de dioses que forman los altares, de gran riqueza e importancia ritual. Estas imágenes pueden comprarse en las innumerables tiendas esotéricas que se encuentran en toda Venezuela y que reciben el nombre de "perfumerías". El uso de este tipo de imágenes, de carácter figurativo, está presente en muchos cultos espiritistas afroamericanos. ¿Cuál es el sentido y la función de estas imágenes religiosas?

Desde el punto de vista de los creyentes, estas imágenes tienen un rol puramente evocativo y simbólico. Los practicantes del culto sostienen, en efecto, que dichas representaciones ayudan al médium a concentrarse, a facilitarle el contacto con los dioses, a "ambientar" el lugar de culto y a mostrar el amor que sienten hacia ellos. Las estatuillas se utilizan pero, según los creyentes, también podrían no utilizarse, puesto que son, como dijo una creyente en la Montaña de Sorte, "sólo imágenes, simples bloques de 
yeso pintados". Lo que quieren dejar claro los creyentes es que bajo ningún concepto ellos efectúan algún tipo de identificación entre la imagen y el dios representado, es decir, entre signo y referente. Lo material y lo espiritual permanecerían así en dos ámbitos totalmente separados. Esta defensa por parte de los creyentes frente a cualquier sospecha de idolatría fue una constante durante todo mi trabajo de campo. De hecho, ellos tildaban la idolatría de "confusión" entre dios y objeto, y vinculaban esta práctica religiosa con una actitud "primitiva", cuando no "salvaje".

Varias observaciones hechas sobre el terreno parecen reforzar la tesis de los creyentes. Por ejemplo: las estatuas que los creyentes utilizan en los altares son compradas y vendidas como simples mercancías. En las estanterías de las tiendas, aparecen como objetos totalmente desacralizados. Los creyentes las compran, las envuelven y las transportan como harían con cualquier otro bien, y en ningún caso parece que tengan la impresión de estar cargando con "un dios" o con "una imagen sagrada". Tampoco se hace a las imágenes ningún tipo de "ritual de pasaje" (Van Genepp 1981) para bendecirlas y transformarlas en imágenes sacras antes de introducirlas en los altares. Si, por ejemplo, una estatua se rompe por accidente, nadie dirá que es un dios quien se ha roto, sino solamente una representación del mismo que puede ser fácilmente remplazada por otra. La imagen ritual no puede identificarse pues con el dios, pero sin embargo lo representa. Los creyentes insisten en el hecho de que si no hay un mínimo valor representacional —es decir, una mínima similitud figurativa entre la apariencia de la imagen y la del dios- la imagen no puede ser utilizada en el contexto ritual. Sin embargo, para poder representar a un dios, es preciso saber cómo es, o, dicho de otro modo, es necesario tener un conocimiento directo de su apariencia. ¿Cómo se accede pues al referente que sirve de modelo para la realización de las imágenes materiales? Es ahí cuando entra en juego la imagen mental. Como sucede en el cristianismo (Belting 1994; Delgado 2002), muchos creyentes afirman que se pueden tener visiones o apariciones $d i$ rectas de María Lionza, quien puede también presentarse en sueños. Estas imágenes mentales se encontrarían en la base de las imágenes materiales, que asegurarían así su lazo representativo con su referente y, en consecuencia, su eficacia ritual.

Como ocurría en relación al vínculo entre alma y cuerpo, la observación directa deja entrever que el lazo entre imagen y referente es más estrecho de lo que uno podría imaginar. El primer elemento que hace sospechar de esta continuidad es sencillamente el hecho de que la gran mayoría de los rituales se hacen frente las imágenes. Se hace difícil de entender que los adeptos inviertan tanto esfuerzo y dinero en montar unos altares cuyo objetivo sería, únicamente, el de "ambientar" el espacio, "ayudar" a la con- 
centración del médium o, como máximo, rendir homenaje a la divinidad. Es, sin embargo, la proximidad que mantienen los adeptos con estas representaciones lo que hace pensar que estas imágenes actúan no únicamente como objetos, sino también como sujetos —es decir, que se establece algún tipo de identificación entre ellas y la divinidad que supuestamente representan. Como en el caso del llamado "catolicismo popular", los creyentes besan las imágenes, les hablan, las visten y se enojan contra ellas cuando no hacen lo prometido. La plegaria o la ofrenda, sin ir más lejos, carecen de sentido si la imagen que se venera no tiene un mínimo poder, ya no de representación, sino de presentación (Gell 1998). Pero el elemento más evidente del valor de sujeto atribuido a las imágenes materiales es que en determinados momentos se da en el culto una identificación total entre imagen y referente que hace que la imagen se convierta plenamente en un sujeto, es decir, que ella sea la divinidad misma. Un ejemplo sacado del trabajo de campo servirá para ilustrar esta tesis.

En 2006, estuve trabajando durante unos meses con un grupo de culto de San Felipe, en el centro occidente de Venezuela. Una mañana, me anunciaron que por la noche iban a celebrar un ritual de posesión a lo largo del cual bajarían muchos espíritus. Pedí en seguida permiso a la materia principal para filmar este evento. Ella me lo concedió, pero añadió que con su autorización no bastaba: tenía que pedir permiso a la Reina María Lionza "en persona". Pregunté sobre cómo hacer tal cosa y ella me invitó a sentarme delante de la imagen principal del altar y fumarme un tabaco, explicándole mentalmente porqué quería filmar la ceremonia y cómo pretendía hacerlo ${ }^{6}$. Seguí todas las instrucciones bajo la atenta mirada de la materia, quien observaba sin perder detalle la forma que iban tomando las cenizas de mi tabaco. Una vez finalizado, lo lancé tres veces al suelo y luego miré a la médium. Estaba sonriente. Ansioso, le pregunté: "ha dado el permiso la Reina o no?", a lo que ella respondió mirando hacia la estatua: "¿No lo viste? Dijo que sí varias veces asentando con la cabeza". Esta atribución de movimientos a las estatuas es vista como algo milagroso, pero relativamente habitual. Circulan, en efecto, múltiples historias sobre representaciones que hablaron, gritaron, comieron o incluso se trasladaron de un sitio a otro. Estos momentos de identificación total aparecen como el ejemplo extremo de la conexión entre representante y representado, como explicitación de un vínculo entre lo material y lo espiritual que, aunque sea negado a nivel del discurso, es totalmente indispensable para la práctica del ritual.

Algo similar sucede con las imágenes mentales, especialmente con las visiones y las apariciones. En las entrevistas, los adeptos definen estas imá-

\footnotetext{
${ }^{6}$ Para el uso del tabaco en el culto a María Lionza, ver Flores (1991).
} 
genes como completamente inmateriales, ausentes de toda corporalidad. Las visiones y las apariciones serían lo más parecido a un alma pura, y darían por ello acceso a un contacto casi directo con la misma divinidad. De nuevo, comentarios hechos por los devotos fuera del ámbito de la entrevista permiten relativizar estas afirmaciones. En efecto, de forma más o menos consciente, los creyentes atribuyen muy a menudo cierto tipo de corporalidad a las visiones o las apariciones. Por ejemplo, es habitual en la Montaña de Sorte, oír que a uno puede aparecérsele la imagen de María Lionza montada sobre un tapir o danta. Cuando esta aparición ocurre, dicen los creyentes que uno puede "oír" el paso fuerte del animal y "oler" el maravilloso perfume de La Reina. Ahora bien, el olor y la pesantez son calidades, en principio, que poseen los cuerpos, mas no las "almas puras". Otro ejemplo, sacado de las ceremonias de trance: uno de las puntos en que muchos creyentes concuerdan es que, justo antes de que el espíritu entre en el cuerpo de la materia, justo cuando está detrás de sus espaldas, hay un momento en que el espíritu se vuelve "visible". Es como una suerte de aparición que tiene lugar justo antes de concluir el momento de substitución espiritual. Lo que mostraría esta breve aparición es el cuerpo del médium intentando amoldarse en el cuerpo del espíritu y, viceversa, el espíritu procurando adaptarse al cuerpo de la materia. Así, si un hombre flaco está incorporando el espíritu de un dios fuerte y corpulento, uno vería, justo antes de la substitución, una suerte de aparición anterior al trance en la que el espíritu trataría de empequeñecerse, a la vez que el cuerpo del practicante haría esfuerzos para ensancharse al máximo. La imagen mental lleva consigo pues una materialidad que indica que, dentro de la lógica del culto, no es posible concebir un dios que no tenga, de un modo u otro, un cuerpo.

Después de hablar de las imágenes materiales y de las imágenes mentales, hago un último apunte sobre las imágenes corporales. El caso de las imágenes corporales en el contexto del ritual —es decir, de la posesiónya ha sido comentado anteriormente. He mostrado cómo, frente al discurso naturalista "oficial", se imponía una práctica que tendía a realzar los puentes entre el ámbito de lo material y el ámbito de lo inmaterial. En el contexto de la imagen corporal fuera del contexto religioso asistimos a un fenómeno similar. La práctica totalidad de las actrices o bailarinas que entrevisté durante mi trabajo de campo eran creyentes del culto y describían la experiencia de la interpretación del papel de María Lionza en términos muy próximos a los de la posesión. Así, era habitual que comentaran que, durante las representaciones, había momentos de "éxtasis", durante los cuales se "identificaban" plenamente con la diosa o incluso se "fusionaban" con ella. El trabajo teatral se definía como una "ofrenda" o un "regalo" que se 
hacía a María Lionza por los favores recibidos, de tal forma que la representación artística adoptaba el sentido de una ceremonia religiosa. Curiosamente, todas las actrices que empezaron interpretando el papel de la diosa sin ser por ello creyentes, terminaron convirtiéndose en adeptas al culto.

Se podrían aportar muchos más datos para poner en evidencia la continuidad existente en el culto entre hombres, dioses, cuerpos, objetos y visiones. Sin embargo, los hasta aquí avanzados son suficientes para demostrar que, frente a un discurso explícito que subraya la discontinuidad entre lo material y lo inmaterial, lo sagrado y la profano, el cuerpo y el alma, asistimos a una práctica religiosa que tiende a tejer constantemente puentes entre dichas esferas. La ambigüedad que se observa en la relación entre el alma y el cuerpo debe inscribirse pues dentro de un sistema de pensamiento más amplio donde, por decirlo en palabras de Descola, naturalismo y analogismo se entremezclan constantemente en función del contexto y de la intencionalidad de los actores sociales. Existe en el culto una corporalidad del alma y una materialidad del cuerpo que no se corresponden con la naturaleza del discurso oficial, que debe sin embargo ser también tomado en cuenta como parte integrante de la cosmovisión del culto.

\section{LAS PALABRAS Y LOS CUERPOS}

A modo de conclusión, quisiera desarrollar brevemente tres ideas que han ido apareciendo a lo largo de este artículo. La primera es de carácter teórico. Resulta sumamente difícil limitar el culto a María Lionza a una ontología precisa: no es, en efecto, ni plenamente naturalista (pese al discurso de los creyentes), ni enteramente analogista (como podría deducirse de una lectura estricta de la tesis de Descola), ni mucho menos animista (aunque ciertos aspectos del culto concuerdan con dicha ontología). ¿Tiene pues algún sentido continuar utilizando estos términos para abordar su estudio? Mi respuesta es que sí. En efecto, aunque inaplicable como concepto descriptivo de la naturaleza del culto, la noción de "naturalismo" resulta útil, pues a través de ella podemos pensar y reflexionar mejor acerca de la lógica del culto. Lo mismo sucede con los conceptos de analogismo o animismo. Sometiendo estos conceptos a prueba, comparándolos con los datos obtenidos durante el trabajo de campo, podemos precisamente iluminar dichos datos dotándolos de significado y valor teórico. Los conceptos no describen ni designan objetivamente los procesos sociales, pero nos ayudan a pensar sobre ellos. Al cerciorarnos de su propia inconsistencia frente a la complejidad de las cosas, de su necesario déficit frente a la naturaleza compuesta, cambiante y a veces paradójica 
del mundo social, podemos pensar y entender mejor el objeto de estudio de la antropología.

Metodológicamente hablando, he intentado poner en evidencia la importancia de concebir el trabajo de campo como la aplicación, no ya de una técnica etnográfica específica, sino de un conjunto de técnicas heterogéneas. En esta investigación, fue precisamente la yuxtaposición de los datos obtenidos mediante la entrevista, la observación participante y las herramientas visuales, lo que permitió comprender mejor la lógica del culto. Más concretamente, lo que esta investigación nos muestra es el carácter netamente contextual y estratégico de la entrevista. Está todavía muy extendida la idea de que los informantes son como diccionarios de su propia "cultura", es decir, que uno les puede preguntar cualquier cosa sobre su forma de ser y vivir en sociedad y que ellos responderán a la interrogación aportando una definición fija y objetiva que, por así decirlo, aguardaba la pregunta del antropólogo para poder ver la luz. Este supuesto implica un doble error: por un lado, presupone que todo individuo es plenamente autoconsciente de los esquemas culturales y sociales que orientan su experiencia y determinan su visión del mundo, lo que es profundamente falso. En segundo lugar, el "efecto diccionario" parte de la posibilidad de una objetividad y neutralidad de la respuesta a la entrevista que deja de lado todas las variables que en dicha respuesta intervienen. Por esta razón, resulta clave que el antropólogo realice las mismas preguntas en diferentes espacios y tiempos, o incluso que entreviste a un mismo individuo cuando está solo y cuando está acompañado. Las respuestas, en función de los contextos, divergirán, y, gracias a esta divergencia, podremos entender mejor los elementos conscientes e inconscientes que condicionan su modo de ser y de actuar.

Dicho esto, quisiera terminar con una breve reflexión acerca de los cultos afroamericanos y de su relación con la concepción occidental del cuerpo. La percepción que ha tenido la antropología sobre estos cultos ha cambiado profundamente durante los últimos decenios. Perseguidos por los Estado y menospreciados o sencillamente ignorados por la academia, no han gozado del reconocimiento universitario ni del prestigio social que detentan las "grandes" religiones monoteístas, o por lo menos las cosmologías amerindias, africanas o aborígenes. Durante muchos años, los cultos afroamericanos han sido considerados cultos menores, algo confusos y circunstanciales. Los apelativos que han hecho más fortuna para referirse a ellos han sido los de cultos "sincréticos" y "pragmáticos", unos términos que, más que describir la naturaleza de estas expresiones religiosas, lo que pretendían era juzgar su legitimidad y su "pedigrí", situándolas un peldaño por debajo de lo que se supondría serían los cultos "puros" u "originales". Sin 
embargo, con el advenimiento de la llamada posmodernidad pareciera que los papeles se hubieran invertido, y los cultos afroamericanos han dejado de ser vistos como una rareza, como un accidente de la historia, para ser considerados como un ejemplo paradigmático y especialmente transparente de la esencia híbrida, cambiante y funcional de toda práctica religiosa y de todo hecho social en general. Su naturaleza explícitamente compuesta y dinámica se adaptaría especialmente bien a las teorías contemporáneas sobre la cultura, que analizan ésta más como un proceso que como un estado, más como un ente relacional que como una entidad aislada. También son los cultos afroamericanos una suerte de ejemplificación de la noción contemporánea de sujeto, que pretende superar la visión cartesiana del "yo". Como he mostrado repetidamente en este artículo, gracias al trance, el individuo puede adoptar varias personalidades, cambiando de identidad en función del contexto. Es esta una visión que encaja fácilmente con la percepción contemporánea del sujeto como un ente múltiple, histórico e inextricablemente social, que adopta varios roles en función de cada contexto - lo que da sentido precisamente a la noción muy extendida de actor social". Finalmente, estos cultos se han erigido en un caso ejemplar para las aproximaciones contemporáneas al estudio del cuerpo y de los sentidos, que tienen como objetivo superar las visiones intelectualistas, reforzando el papel de la experiencia corporal individual en la construcción de significados sociales.

¿Cómo nos puede ayudar el estudio de la noción de "cuerpo" en el culto a María Lionza para analizar la visión del cuerpo en la cultura occidental? En las sociedades "occidentales" operamos también en relación al cuerpo bajo un discurso propio del dualismo naturalista (Le Breton 2001). Por ejemplo: preguntada por si le gustaría ser madre en un futuro próximo, una chica noruega de 24 años residente en Barcelona respondía: "sí, creo que quiero ser madre, pero no sé si es el momento idóneo. No sé si soy yo quien quiere ser madre o si es mi cuerpo que me lo pide. Este comentario deja entrever que el cuerpo es visto como regido por su propia lógica - la de los ciclos naturales de la vida- y la persona por la suya - la de los ciclos culturales de la sociedad. Habría una discontinuidad entre persona y cuerpo que se fundamentaría en la distinción más elemental entre Cultura y Naturaleza. Sin embargo, cabe también preguntarse si, como sucede con los cultos afroamericanos, ese dualismo tajante no tiene que ver más con el ámbito del discurso que con el ámbito de la acción, y si, en consecuencia, entre cuerpo, persona y sociedad no existe, en el fondo, una necesaria e indisoluble continuidad, gracias a la cual el cuerpo no quedaría limitado a ser el mero soporte de la persona, sino que se reivindicaría como parte integrante de ésta, espacio de identidad personal y de relación social. 


\section{BIBLIOGRAFÍA CITADA}

Amselle, J-L. 1999 [1990]. Logiques métisses. París: Payot.

Astuti, R. 2001. "Are we all natural dualists? A cognitive developmental approach". The Journal of the Royal Anthropological Institute 7 (3): 429-447.

Aumont, J. 1990. L'image. París: Nathan.

Barreto, D. 1990. "Perspectiva histórica del mito y culto a María Lionza". Boletín Americanista 39-40: 9-26.

Barreto, D. 1995. "El mito y culto de María Lionza: identidad y resistencia popular", en Historias de identidad urbana: 61-73. Caracas: Universidad Central de Venezuela.

Barreto, D. 1998. Genealogía de un mito. Tesis de Doctorado en Antropología. Caracas: Universidad Central de Venezuela.

Belting, H. 1994. Likeness and presence. Chicago: The University of Chicago Press.

Belting, H. 2004 [2001]. Pour une anthropologie des images. París: Gallimard.

Bourdieu, P. 1994. Raisons pratiques. París: Éditions du Seuil.

Canals, R. 2010a. L'image nomade. Un essai sur les représentations de la déesse María Lionza au Venezuela. Saarbrücken: Éditions Universitaires Éuropéennes.

Canals, R. 2010b. "Studying images through images. A visual ethnography of the cult of María Lionza in Venezuela", en S. Stephen (ed.), Visual Research Methods in the Social Sciences: 225-238. Nueva York: Routledge.

Canals, R. 2011a. "Les avatars du regard dans le culte à María Lionza". L'Homme. Revue Française d'Anthropologie 198-199: 213-226.

Canals, R. 2011b. "Ritos en el exilio. Función y significado del ritual en la diáspora". Actas del XII Congreso de Antropología de la FAAEE. León: Universidad de León.

Clarac De Briceño, J. 1970. "El culto de María Lionza”. América Indígena XXX (2): 359374.

Clarac De Briceño, J. 1983. "Una religión en formación en una sociedad petrolera”. Boletín Antropológico 4: 29-33.

Clarac De Briceño, J. 1996. La enfermedad como lenguaje en Venezuela. Mérida: Universidad de Los Andes.

Descola, P. 2005. Par-delà nature et culture. París: Gallimard.

Delgado, M. 2002. Luces iconoclastas. Barcelona: Ariel.

Fernández, A y D. Barreto. 2001-2002. "El culto de María Lionza: del pluralismo espiritista a la contestación". Antropológica 96: 13-30.

Ferrándiz, F. 1992. "Dimensions of nationalism in a venezuelan possession cult: the crystallization of an oral tradition". Kroeber Anthropological Society 75-76: 28-47.

Ferrándiz, F. 1995. "Itinerarios de un médium". Antropología 10: 133-166.

Ferrándiz, F. 1996. "Intersubjetividad y vídeo etnográfico. Holguras y texturas en la grabación de ceremonias espiritistas en Venezuela", en M. García et al. (eds.), Antropología de los sentidos. La vista: 105-123. Madrid: Celeste ediciones.

Ferrándiz, F. 1999. "El culto de María Lionza: tiempos, espacios, cuerpos". Alteridades 9 (18): $39-55$

Ferrándiz, F. 2002. "Calidoscopios de género: cuerpo, masculinidad y supervivencia en el espiritualismo de Venezuela". Alteridades 12: 83-92.

Ferrándiz, F. 2004. Escenarios del Cuerpo. Bilbao: Universidad de Deusto. 
Flores, D. 1991. La adivinación por el tabaco en el culto a María Lionza. Maracaibo: Universidad de Zulia.

Garmendia, H. 1980. María Lionza: ángel o demonio. Caracas: Seleven.

Gell, A. 1998. Art and agency. Oxford: Clarendon Press.

Ingold, T. 2002 [2000]. The perception of the environment. Londres: Routledge.

Jiménez Sierra, E. 1971. La venus venezolana. Caracas: Chicuramay.

Latour, B. 1992. Ciencia en acción. Barcelona: Labor.

Le Breton, D. 2001. Anthropologie du corps et modernité. París: PUF.

Manara, B. 1995. María Lionza. Su identidad, su culto y la cosmovisión anexa. Caracas: Universidad Central de Venezuela.

Mintz, S. y R. Price. 1992 [1976]. The birth of african-american culture. Boston: Beacon Press.

Pink, S. 2009. Doing sensory ethnography. Londres: Sage.

Pollack-Eltz, A. 1972. María Lionza, mito y culto venezolano. Caracas: Universidad Católica Andrés Bello.

Pollack-Eltz, A. 1994. La religiosidad popular en Venezuela. Caracas: San Pablo.

Salazar, H. 1998. Yara. La historia de María Lionza. Caracas: El Aragüeño.

Schaeffer, J-M. 2005. "Quelles vérités pour quelles fictions". L'Homme 175-176: 19-36.

Van Genepp, A. 1981 [1909]. Les rites de passage. París: Picard.

Fecha de recepción: 24 de octubre de 2011

Fecha de aceptación: 26 de marzo de 2012 